\title{
Salicylic Acid and Cytokinin Protects Maize Plant against Glyphosate Action
}

\author{
H.E. Deef \\ Botany Deptartment, Faculty of Science, Zagazig University, \\ Zagazig, Egypt.
}

\begin{abstract}
7 HE MITIGATING effects of salicylic acid (SA) and cytokinin . (CK) against glyphosate stress on young maize plants were investigated. The application of glyphosate has harm effects on maize plants, i.e. plants became shorter, chlorosis, leaves turned to yellow more or less dry in some parts then died. The morphological changes associated with decrease in the chlorophyll content; meanwhile the levels of protein, proline and the activity of ascorbate peroxidase (APX), catalase (CAT), peroxidase (POD) and superoxide dismutase (SOD) were increased. Available data suggest that the protective effect of SA and $\mathrm{CK}$ was accompanied with increase in chlorophyll content and reduction in proline and the activity of APX, CAT, POD and SOD in comparison with glyphosate treatment. The combination between SA and CK not alleviate the harm effects of glyphosate on maize. The present results gave an insight about the use of SA and CK alone in alleviated in some extent the detrimental effects due to the glyphosate action.
\end{abstract}

Keywords: Glyphosate, Maize, Salicylic acid, Cytokinin, Protein, Proline, Antioxidative enzymes.

Application of herbicides considered one of the important factors affecting crop production. It was reported that, excess herbicides damage the weeds and crops through changes the metabolic and physiological processes within the plant cells (Song et al., 2008; Yin et al., 2008 and Jiang \& Yang, 2009). Glyphosate [(N-phosphonomethyl) glycine] is a highly effective broad-spectrum, nonselective, systemic, post-emergence herbicide used extensively worldwide (Tan et al., 2006 and Vila-Aiub et al., 2008). Glyphosate degradation appears to be very slow or does not take place in higher plants (Vila-Aiub et al., 2007). Most herbicides inhibit plant metabolic pathways or physiological processes by interacting with specific proteins (Dayan et al., 2010). The target site of glyphosate action is the enzyme 5-enoylpyruvylshikimate-3-phosphate synthase (EPSPS) of the shikimate pathway (Ge et al., 2010). Inhibition of EPSPS leads to reduced feedback inhibition of the pathway, resulting in massive carbon flow to shikimate-3-phosphate, which is converted into high levels of shikimate (Stephen \& Stephen, 2008). Salbego et al. (2010) showed that the inhibition of this enzyme causes an accumulation of shikimic acid and a consequent reduction in the biosynthesis of aromatic amino acids, auxins and vitamins as well as a number of key metabolites produced via the shikimate pathway. This leads to a suspension of plant growth, and in turn to plant death. Glyphosate also disrupts chloroplasts, membranes, cell walls; alters protein, nucleic acid

Corresponding author email: Deef66@yahoo.com 
synthesis, photosynthesis, respiration; reduces chlorophyll, and other porphyrin compound synthesis (Singh et al., 2012). A lower amount of leaf chlorophyll is a distinguishing characteristic in plants exposed to sublethal concentrations of glyphosate (Tan et al., 2006).

Glyphosate leads to oxidative stress in plants which is most probably a secondary effect of the blocked shikimate pathway (Sergiev et al., 2006). Excessive herbicides and other toxic organic substances are able to induce intracellular over-production of reactive oxygen species (ROS) and damage the plant cells (Yin et al., 2008). Plants utilize a well-organized antioxidative defense system comprising enzymatic system to scavenge ROS (Liu et al., 2009). The cooperative function of these antioxidants such as SOD, APX and CAT plays an important role in scavenging ROS and maintaining the physiological redox status of organisms (Cho \& Seo, 2005).

Salicylic acid (SA) is an endogenous, phenolic growth regulator which can act as a non-enzymatic antioxidant. It is considered to be a plant growth regulator, which plays an important role in regulating a number of plant physiological processes including photosynthesis (Arfan et al., 2007 and Hayat et al., 2010). SA provides protection against biotic and abiotic stresses of plants (Singh et al., 2012). Exogenous SA has been shown to ameliorate the damaging effects of heavy metals in rice (El-Khallal et al., 2009), salinity in wheat (Eraslan et al., 2007) drought in maize (Noreen et al., 2009) and herbicides in barley (Ananieva et al., 2004). In addition, the important protective action of SA probably reflects its ability to induce the expression of genes coding not only for PR-proteins, but also, for genes encoding extension in Arabidopsis plants (Merkouropouls et al., 1999). Burkhanova et al. (1999) reported that SA induced synthesis of heat shock proteins in tobacco plants and fast activation of the $48 \mathrm{kDa}$ protein kinase, which was identified as SIPK (salicylic acid induced protein kinase).

Cytokinin promotes cell division and is implicated in plant growth and development. It can not only enhance plant growth but also can improve stress tolerance (Schmidt \& Zhang, 1997). Treatment with kinetin protects creeping bent grass subjected to drought (Zhang \& Schmidt, 2000), and use of zeatin riboside alleviates heat stress injury (Liua et al., 2002).

The objective of this work was to characterize several biochemical parameters that are responsive to salicylic acid and cytokinin. In addition to investigate whether these were associated with partial alleviation of glyphosate toxicity through regulation of the antioxidant status of maize plants.

\section{Materials and Methods}

\section{Plant materials and treatments}

As a model system, maize plants (Zea mays L. cv. Kneza-640) were used. Grains of maize were washed with running tap water and then soaked for $30 \mathrm{sec}$

Egypt. J. Agron. 35, No. 2 (2013) 
in $70 \%$ ethanol followed by disinfection with $20 \%$ (v/v) sodium hypochlorite for $20 \mathrm{~min}$ and rinsed three times with sterile distilled water. Grains were soaked in tap water for $24 \mathrm{~h}$, and put on moistened filter paper for germination in darkness (at $25^{\circ} \mathrm{C}$ ). Two-day old seedlings were swoon in each pot containing sandy soil ( $85 \%$ sand, $10 \%$ silt and $5 \%$ clay) at a relative humidity of $50 \pm 4 \%$, day/night temperature $30 / 20 \pm 2{ }^{\circ} \mathrm{C}$, and light intensity of $350.67 \pm 4.16$ Lux. in the greenhouse at the Botany Department, Faculty of Science, Zagazig University, during April 2013. The pots were irrigated with a half-strength Hoagland's solution with trace microelements. The plants with fully developed second leaves were divided into five groups treated (sprayed, approximately $3 \mathrm{ml}$ per plant) with:

$\mathrm{C}=$ Distilled $\mathrm{H}_{2} \mathrm{O}$ (control).

$\mathrm{G}=$ Aqueous solutions of glyphosate $(10 \mathrm{mM})$.

$\mathrm{GS}=$ Aqueous solutions of glyphosate $(10 \mathrm{mM})$ and $\mathrm{SA}(0.5 \mathrm{mM})$.

$\mathrm{GC}=$ Aqueous solutions of glyphosate $(10 \mathrm{mM})$ and $\mathrm{CK}(0.1 \mathrm{mM}$ Benzylaminopurine).

$\mathrm{GSC}=$ Aqueous solutions of glyphosate $(10 \mathrm{mM}), \mathrm{SA}(0.5 \mathrm{mM})$ and $\mathrm{CK}$ (0.1 mM benzyl adenine).

The parameters investigated were measured after 10 days of the treatment due to the half-life of glyphosate on foliage being estimated at 10.4 to 26.6 days (Tu, 1994). Morphological appearance was recoded by imaging with a digital video camera interfaced to a computer running software from the same manufacturer (SPOT 4.6). The second fully developed leaf was used as a source material for biochemical analyses.

\section{Photosynthetic pigments}

The contents of the photosynthetic pigments chlorophyll $a$ (chl $a$ ), chlorophyll $b(\mathrm{chl} b)$ and Carotenoides in fresh leaves were determined using the spectrophotometric method recommended by Metzner et al. (1965) and described by Hassanein et al. (2009). The concentration of each pigment $(\mu \mathrm{g} / \mathrm{ml})$ was calculated using the following equations:

Chl $a=10.3 \mathrm{E}_{663}-0.918 \mathrm{E}_{644}$

Chl $b=19.7 \mathrm{E}_{644}-3.87 \mathrm{E}_{663}$

Carotenoides $=4.2 \mathrm{E}_{452}-(0.0264 \mathrm{chl} a+0.4260 \mathrm{chl} b)$

Finally, the pigment contents were expressed as $\mathrm{mg} \mathrm{g}^{-1}$ fresh weight (FW).

\section{Total proteins}

Total protein was determined according to the method described by Bradford (1976) with bovine serum albumin as a standard. An amount of $1 \mathrm{gm}$ of sample was ground in a mortar with $5 \mathrm{ml}$ of phosphate buffer $(\mathrm{pH} \mathrm{7.6)}$ ) and was then centrifuged at $8000 \mathrm{rpm}$ for $20 \mathrm{~min}$. 30 $\mu \mathrm{l}$ of different samples were mixed with $70 \mu \mathrm{l}$ of distilled water then $2.9 \mathrm{ml}$ of Coomassi Brillaint Blue solution was added and mixed thoroughly. The tubes were incubated for $5 \mathrm{~min}$ at room temperature and absorbance at $600 \mathrm{~nm}$ was recorded against the reagent blank. A standard curve of Absorbance $(600 \mathrm{~nm})$ versus concentration (ug) of protein was calculated. 
Proline

$1 \mathrm{gm}$ of sample was extracted with phosphate buffer $(\mathrm{pH} \mathrm{7.6)}$ and then centrifuged at $8000 \mathrm{rpm}$ for $20 \mathrm{~min}$. Proline was assayed according to the method described by Bates et al. (1973). $2 \mathrm{ml}$ of extract, $2 \mathrm{ml}$ of acid ninhydrin and $2 \mathrm{ml}$ of glacial acetic acid were added and incubated for $1 \mathrm{~h}$ in a boiling water bath followed by an ice bath. The absorbance was measured at $520 \mathrm{~nm}$ using Spekol Spectrocololourimeter VEB Carl Zeiss. A standard curve was obtained using a known concentration of authentic proline.

\section{Protein extraction for SDS-PAGE}

For SDS-PAGE, seedling tissue of each sample was ground to powder under liquid nitrogen and melted in ice-cold extraction buffer $(50 \mathrm{mM}$ Tris- $\mathrm{HCl}, \mathrm{pH} 8$, $10 \mathrm{mM} \mathrm{NaCl}, 1 \%$ SDS, 5\% 2-mercaptoethanol, $0.1 \mathrm{mM}$ PMSF, $0.1 \mathrm{mM}$ DTT), followed by centrifugation at $10000 \mathrm{rpm}$ at $4{ }^{\circ} \mathrm{C}$ for $15 \mathrm{~min}$. Proteins of the clear supernatants obtained after centrifugation were stored at $-20{ }^{\circ} \mathrm{C}$ until used.

\section{One-dimensional SDS-PAGE}

Proteins, $30 \mathrm{ug}$ of each sample, were separated by SDS-PAGE according to the method of Laemmli (1970). The separation was performed with a $10 \%$ separating gel and a $4 \%$ stacking gel using a protein vertical electrophoresis unit (Hoefer Scientific Instruments). Electrophoresis was started at $10 \mathrm{~mA}$ constant current until the tracking dye entered the separating gel and continued at $25 \mathrm{~mA}$ until the tracking dye reached the end of the gel. Protein subunit bands were stained with coomassie blue R-250 by standard techniques. The molecular weights of standard proteins added in a comparison ladder (in $\mathrm{kDa}$ as follows: $30,40,50,60,80,120$ and $220 \mathrm{kDa}, 7$ bands) were used to determine molecular weight of the added proteins.

\section{Antioxidative enzymes}

Extraction of enzymes

Fresh leaf tissue $(0.5 \mathrm{~g})$ was harvested and homogenized under ice-cold conditions in $5.0 \mathrm{ml}$ of extraction buffer, containing $50 \mathrm{mM}$ phosphate buffer (pH 7.5), $1 \%$ polyvinyl pyrrolidone (PVP), $0.5 \%$ Triton X100, and $1 \mathrm{mM}$ EDTA. The homogenate was centrifuged at $10,000 \mathrm{rpm}$ for $20 \mathrm{~min}$ at $4{ }^{\circ} \mathrm{C}$. The supernatant was used to measure the activities of SOD, APX and GR.

\section{Ascorbate peroxidase (APX)}

APX activity was measured by the method of Nakano \& Asada (1987). The reaction mixture $(1 \mathrm{ml})$ contained $100 \mathrm{mM}$ potassium phosphate buffer $(\mathrm{pH}$ 7.0), $0.5 \mathrm{mM}$ ascorbate, $0.3 \mathrm{mM} \mathrm{H} \mathrm{H}_{2}$ and enzyme extract. The oxidation of ascorbic acid was measured by the decrease in absorbance at $290 \mathrm{~nm}$ for $3 \mathrm{~min}$ using UV-vis spectrophotometer (Model Ultrospec 3000, Pharmacia Biotech, USA). The enzyme activity was calculated using the extinction coefficient $2.8 \mathrm{mM}^{-1} \mathrm{~cm}^{-1}$ and expressed in enzyme units $\left(100 \mathrm{~g} \mathrm{FW}^{-1}\right.$. One unit of enzyme is the amount necessary to decompose $1 \mu \mathrm{mol}$ of substrate per min at $25^{\circ} \mathrm{C}$.

\section{Catalase (CAT)}

CAT activity was assayed by measuring the initial rate of hydrogen peroxide disappearance using the method of Velikova et al. (2000). One milliliter of 
catalase assay reaction mixture contained $10 \mathrm{mM}$ potassium phosphate buffer, $\mathrm{pH} 7.0$ with an appropriate aliquot of enzyme extract and $33 \mathrm{mM}$ hydrogen peroxide. The decrease in hydrogen peroxide was followed as a decline in optical density at $240 \mathrm{~nm}$ and the activity was calculated using the extinction coefficient of $40 \mathrm{mM} \mathrm{cm}^{-1}$ for hydrogen peroxide.

Peroxidase (POD)

POD was measured and determined by Kokkinakis \& Brooks (1979) method. Activity of peroxidase was determined based on the appearance of brown colors resulting from guaiacol oxidation in the presence of hydrogen peroxide. Reaction mixture consisted of $50 \mu \mathrm{L}$ sample extract, $2.6 \mathrm{~mL}$ of $0.1 \mathrm{M}$ sodium phosphate buffer at $\mathrm{pH} 6.1$ and $0.3 \mathrm{~mL}$ of $1 \%$ guaiacol was added into the solution. A total of $0.3 \mathrm{~mL}$ of $30 \% \mathrm{H}_{2} \mathrm{O}_{2}$ was added prior to reaction. Changes in absorbance at $420 \mathrm{~nm}$ were followed for three min using a spectrophotometer (Bio-Rad smartspec plus, USA). Peroxidase activity was calculated using the formula below and expressed as unit/mg protein:

Specific activity of peroxidase $=\underline{\text { Total activates of the sample }}$

Total activities $=$ Abs. $\mathrm{x}$ dilution factor $\times 1000$

Protein content of the sample

Volume of enzyme used in the assay

Superoxide dismutase (SOD)

SOD activity was measured according to the method of Beauchamp \& Fridovich (1971). The reaction mixture $(1.5 \mathrm{ml})$ contained $100 \mathrm{mM}$ potassium phosphate buffer ( $\mathrm{pH} 7.8$ ), $0.1 \mathrm{mM}$ EDTA, $13 \mathrm{mM}$ methionine, $2.25 \mathrm{mM}$ nitroblue tetrazolium (NBT), $60 \mathrm{mM}$ riboflavin and enzyme extract. After mixing, the contents in the cuvet were illuminated for $10 \mathrm{~min}$. A tube with enzyme extract kept in the dark served as a blank, while the control tube which contained no enzyme extract was kept in the light. The absorbance was measured at $560 \mathrm{~nm}$ against a blank using a UV-vis spectrophotometer (Model Ultrospec 3000, Pharmacia Biotech). NBT reduction in the light was measured in the presence and absence of enzyme extract. SOD activity is presented as absorbance of control minus absorbance of sample, giving the total inhibition. One unit of activity is the amount of enzyme required for $50 \%$ reduction in color and was expressed in units of the enzyme $100 \mathrm{~g}^{-1} \mathrm{FW} \mathrm{h}^{-1}$.

Statistical analysis

All data were reported as mean \pm standard deviation $( \pm \mathrm{SE})$ for the three independent samples $(n=3)$ and subjected to one-way analysis of variance (ANOVA) using Analyst software. The LSD values were then computed at 5\% level of probability for comparison of the difference between means.

\section{Results and Discussion}

Effect of glyphosate, SA and CK applied alone and in combination on morphological appearance, growth and pigments of maize leaves

Ten days after treatment with $10 \mathrm{mM}$ glyphosate, maize plants showed severe changes in morphological appearance and plants became shorter than the control. It caused leaf-tip chlorosis; leaves turned yellow and become more or less dry in some parts with lower water contents, then died (Fig.1\&2). Glyphosate is among the amino acid synthesis inhibitors herbicides which are readily absorbed through plant foliage and translocated in the phloem. Efficient translocation and a lack metabolism of glyphosate in most plant species (Franz 
et al., 2000) allows to accumulate in and inhibit apical meristems. This inhibition encourages sprouting of axillary buds (Gilreath et al., 2001), which results in a witch's broom' appearance of affected plants. Glyphosate treatment of corn and cotton seedlings inhibited polar auxin transport (Gilreath et al., 2001) and was associated with enhanced rates of auxin metabolism in seedlings.

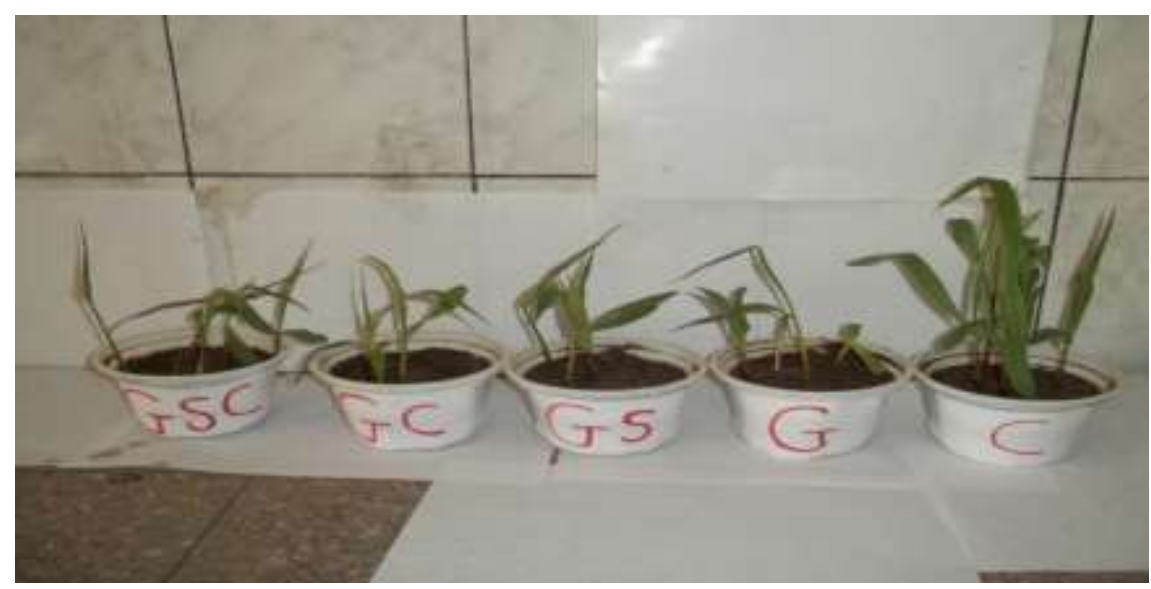

Fig.1. Glyphosate, cytokinin and SA treatments effects on the growth and morphology of Zea mays plants.

$\mathrm{C}=$ Distilled $\mathrm{H}_{2} \mathrm{O}, \mathrm{G}=$ Aqueous solutions of glyphosate $(10 \mathrm{mM}), \mathrm{GS}=$ Aqueous solutions of glyphosate $(10 \mathrm{mM})$ and $0.5 \mathrm{mM}$ of $\mathrm{SA}, \mathrm{GC}=$ Aqueous solutions of glyphosate $(10 \mathrm{mM})$ and $0.1 \mathrm{mM}$ of $\mathrm{CK}, \mathrm{GSC}=$ Aqueous solutions of glyphosate $(10 \mathrm{mM})$ and $0.5 \mathrm{mM}$ of the $\mathrm{SA}$ and $0.1 \mathrm{mM}$ of the CK.

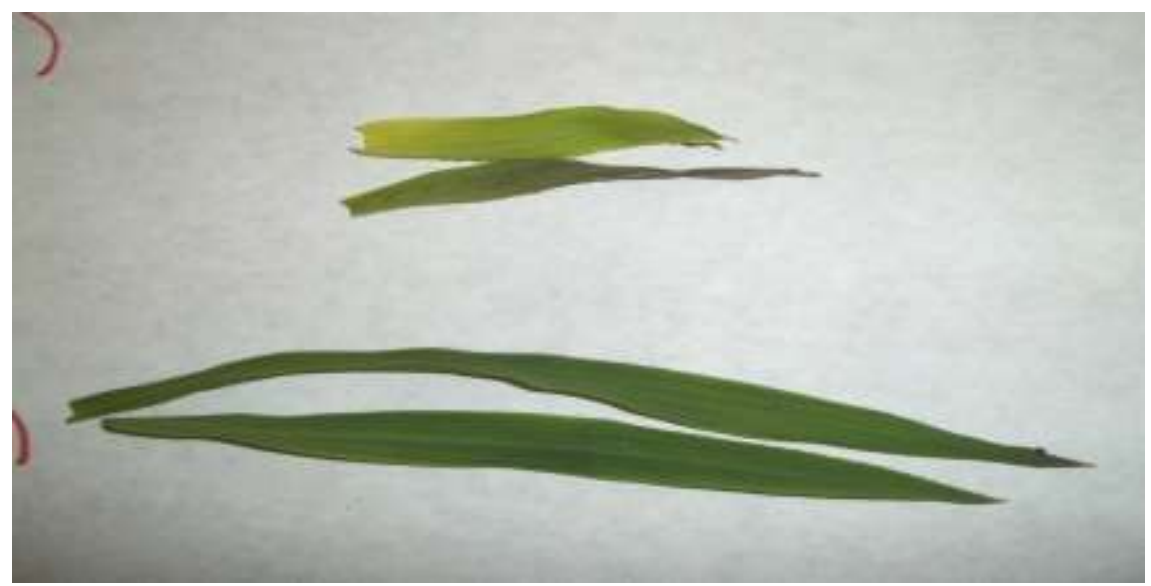

Fig.2. Zea mays leaves turned to yellow and become drier with glyphosate treatment (upper) compared with the control (lower).

Glyphosate inhibit synthesis of the aromatic amino acids tyrosine, tryptophan, and phenylalanine (Singh et al., 2012). Glyphosate symptoms are not apparent until three to five days after treatment and include stunting, foliage

Egypt. J. Agron. 35, No. 2 (2013) 
discoloration, and slow plant death. This injury could be due to oxidative stress leading to death of some leaf parts (Fig. 1\&2). Glyphosate application could rise the superoxide levels and cause ROS accumulation which accompanied by lipid peroxidation (Radwan, 2012). Accumulation of ROS could not only cause lipid peroxidation but also induce membrane damage and cause severe disturbances in the physiological metabolism of plants leading to cell death and accelerated plant senescence (Xu et al., 2006 and Ogweno et al., 2009). Many assume that insufficient aromatic amino acid production to maintain necessary protein synthesis is the primary effect of glyphosate, and this is consistent with the slow development of symptoms (Stephen \& Stephen, 2008).

In comparison with the glyphosate treatment, plants treated with glyphosate plus CK and SA showed a healthier appearance. Morphologically, using CK and SA alone appeared to be better than using a combination of them for protecting maize plants against glyphosate injuries (Fig.1\&2). SA is known to regulate the antioxidant status through inhibition or activation of the antioxidant enzymatic system scavenging the generated ROS (Apel \& Hirt, 2004). Salicylic acid also uncouples oxidative phosphorylation which leads to increased ADP: ATP and AMP: ATP ratios in the cell (Hawley et al., 2012). Singh et al. (2012) showed that SA application may be responsible for activation of defense genes. Meanwhile the pretreatment with benzyladenine (CK) reduce herbicide toxicity and treated plants with $\mathrm{CK}$ might become more tolerant against oxidative stress (Kiadó, 2005). Cytokinin could act as a protector by activation of the antioxidant defense systems and caused an increase in glutathione (GSH) which participate in the regulation of the cell antioxidant systems (Sergiev et al., 2006).

The combination of SA and CK reduced the improving effect of each alone on glyphosate stress. This result is in agreement with Argueso et al. (2012) who demonstrated that SA negatively regulates cytokinin signaling. They added that the negative regulation of SA-dependent defense responses and that a complete phosphorelay cascade, initiated at the level of cytokinin receptors and culminating in type-A ARR phosphorylation and activation. This type-A ARR function is promoted by cytokinin and occurs downstream of SA; in the absence of functional type-A ARRs, defense gene expression.

Pigment contents and particularly chlorophyll parameters were used to elucidate the mode of action of herbicides on plant physiology (Conrad et al., 1993). Reduction in Chl. $a$ and Chl. $b$ in maize leaves as a result of application of glyphosate was found (Fig.3). Chlorophyll degradation that leads to chlorosis might be occurred in response to ROS generation in glyphosate sprayed leaves (Mittler et al., 2004 and Sergiev et al., 2006). Reports for maize, barley, tobacco and sunflower (Mateos-Naranjo et al., 2009) showed a high sensitivity of chlorophyll to glyphosate action. Nandula et al. (2007) verified that the chlorophyll content decreased at 7 days after glyphosate treatment. The decrease of chlorophyll content may be due to an increase of chlorophyll degradation or to a decrease of chlorophyll synthesis (Santos, 2004). Moreover herbicide stress 
induced a reduction in the number of chloroplasts (Cakmak et al., 2009). Glyphosate prevent chlorophyll synthesis by inhibiting the formation of the porphyrin precursor d-amino levulinic acid (Zaidi et al., 2005).

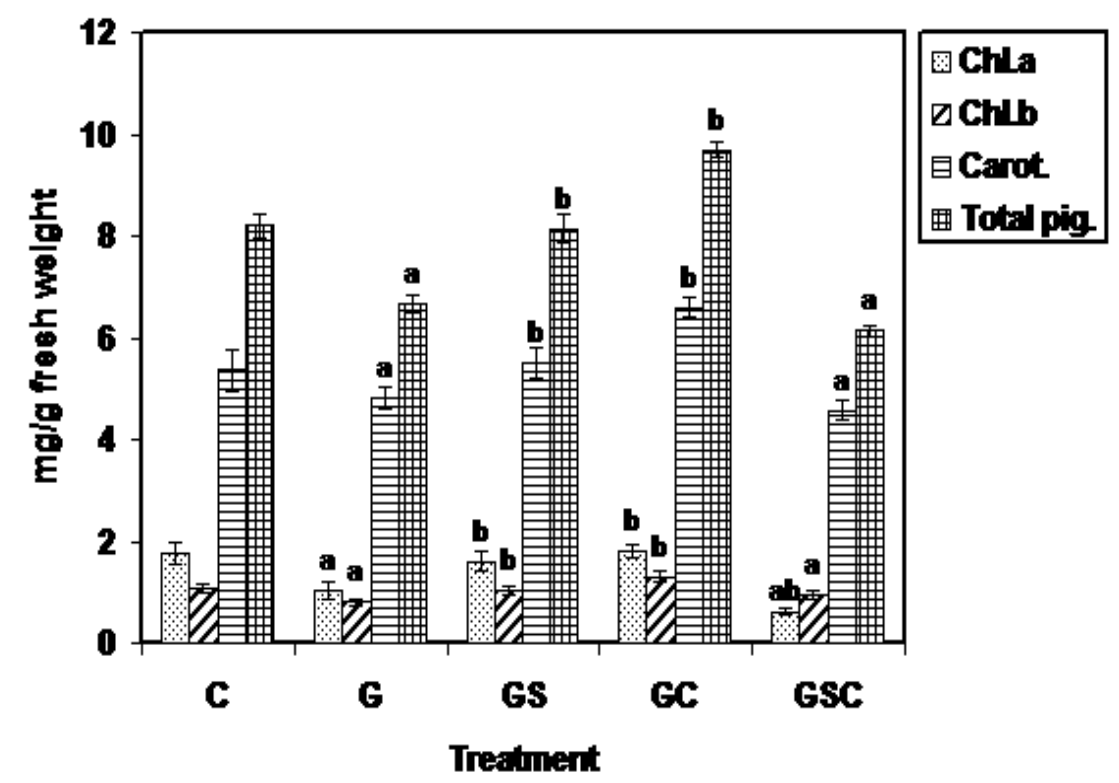

Fig.3. Effect of glyphosate, SA and CK applied alone and in combination on the pigment contents $(\mathrm{mg} / \mathrm{g}$ fresh weight) of maize leaves.

Chl $a=$ Chlorophyll $a$, Chl $. b=$ Chlorophyll $b$, Carot. $=$ Carotenoides,

Means within a column followed by $\mathrm{a}, \mathrm{b}$ are significantly different from the $\mathrm{C}$ (control) and $\mathrm{G}$ (glyphosate) treated samples, respectively.

It was found that $\mathrm{SA}$ and $\mathrm{CK}$ alone with glyphosate increased the pigment contents, and in combination with glyphosate significantly retarded the pigment contents of maize plants (Fig.3). Khodary (2004) observed a significant increase in growth characteristics, pigment contents and photosynthetic rate in maize, sprayed with SA. CK increase plant tolerance (Iqbal et al., 2006a) and considered as $\mathrm{ABA}$ antagonists and auxins antagonists/synergists in various processes in plants (Pospisilova, 2003). It was hypothesized that cytokinin could increase plants tolerance by interacting with other plant hormones, especially auxins and ABA (Iqbal et al., 2006b). CK also retard senescence, having effect on membrane permeability to mono and divalent ions, and localized induction of metabolic sinks (Letham, 1978).

The alteration in pigment content due to combination between CK, SA and glyphosate may be parts of the pathway that regulates plant's response in this situation. It is postulated that there is an antagonistic effect between CK and SA in plants at low temperature which may negatively effects on the plant growth via controlling the expression level of CYCD3;1 gene (Xia et al., 2008).

Egypt. J. Agron. 35, No. 2 (2013) 
Effect of glyphosate, SA and CK applied alone and in combination on protein and proline of maize leaves

A noticeable increase in the total proteins in glyphosate with or without $\mathrm{CK}$ and SA treated leaves compared with the control (Fig. 4). The increase in the proteins through treatment with glyphosate may be result of increase protein synthesis (Peixoto et al., 2006) or less protein degradation (Çag et al., 2009). The stimulation of protein synthesis lead to protein accumulation may involve in sequences of enzymes activity as defense mechanism against herbicide stress (Peixoto et al., 2006). Five CBF regulon genes encode proteins that have been predicted to have protease or protease inhibitor activity (Maruyama et al., 2004 and Vogel et al., 2005). A possible explanation for this is that these proteins could have a regulatory role during stress by modifying activity of a transcriptional regulator or component of a signal transduction pathway. In support of this notion, Levy et al. (2004) identified a mutant in the chloroplast proteolytic machinery which exhibited impaired photoprotection and photosynthesis upon stress. In agreement with our results, it was reported that SA results in pronounced increase in total protein contents and formation of new proteins in pea and sunflower leaves as tolerance tools (Çag et al., 2009). Meanwhile CK (Benzylaminopurine) stimulate RNA and protein biosynthesis, producing a number of growth-enhancing effects (Skinner et al., 2009).

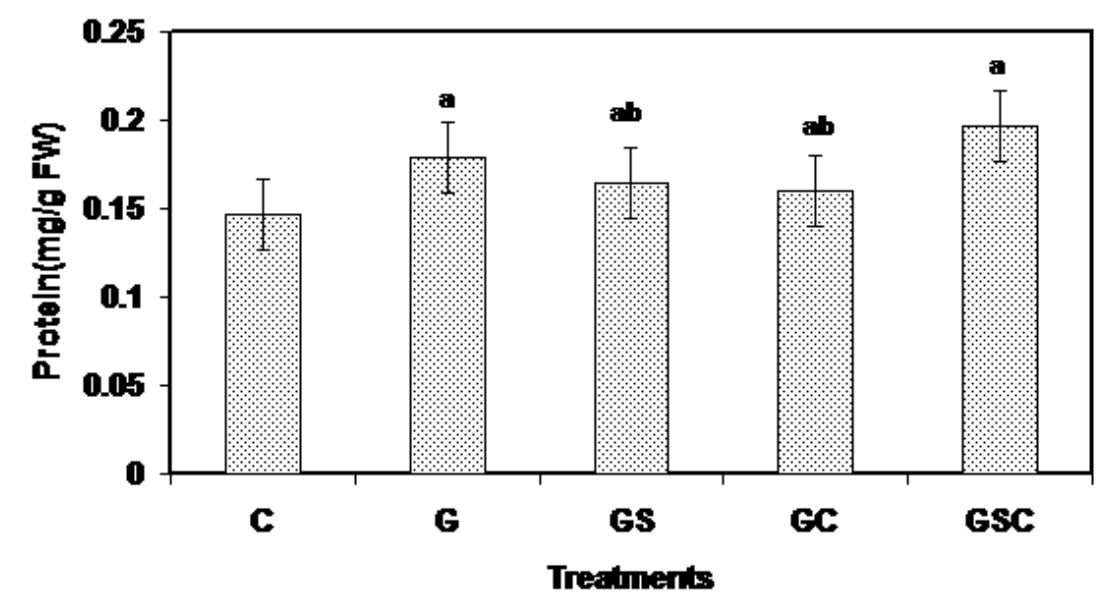

Fig.4. Effect of glyphosate, SA and CK applied alone and in combination on the protein contents of maize leaves.

Means within a column followed by $\mathrm{a}, \mathrm{b}$ are significantly different from the $\mathrm{C}$ (control) and G (glyphosate) treated samples, respectively.

Our results showed a significant accumulation of proline content with glyphosate treatment (Fig.5), in agreement with El-Taybe \& Zaki (2009). Proline is one of the most common compatible osmolytes in stressed plants (Mafakheri et al., 2010), help in protection of macromolecules during 
dehydration (Yancey et al., 1982), and act as a hydroxyl radical scavenger (Zhang et al., 2001). Proline has multiple functions, such as osmoticum, scavenger of free radicals, protector role of cytoplasmic enzymes, source of nitrogen and carbon of post stress growth, stabilizer of membranes, machinery for energy to regulate redox potential (Ashraf \& Foolad, 2007). SA and CK alone increase proline content compared with control and decreased the glyphosate-enhanced proline accumulation, i.e. increase plant tolerance to glyphosate. SA regulated the level of proline, total amino acids and soluble protein content in tobacco leaves (Wei et al., 2006). Peleg \& Blumwald (2011) showed that elevated CK levels promoted survival under stress conditions, inhibited leaf senescence and induced increased proline levels.

The combination between CK, SA and glyphosate was not effect on glyphosate-enhanced proline accumulation compared with control. It is postulated that there is an antagonistic on the plant tolerance to glyphosate.

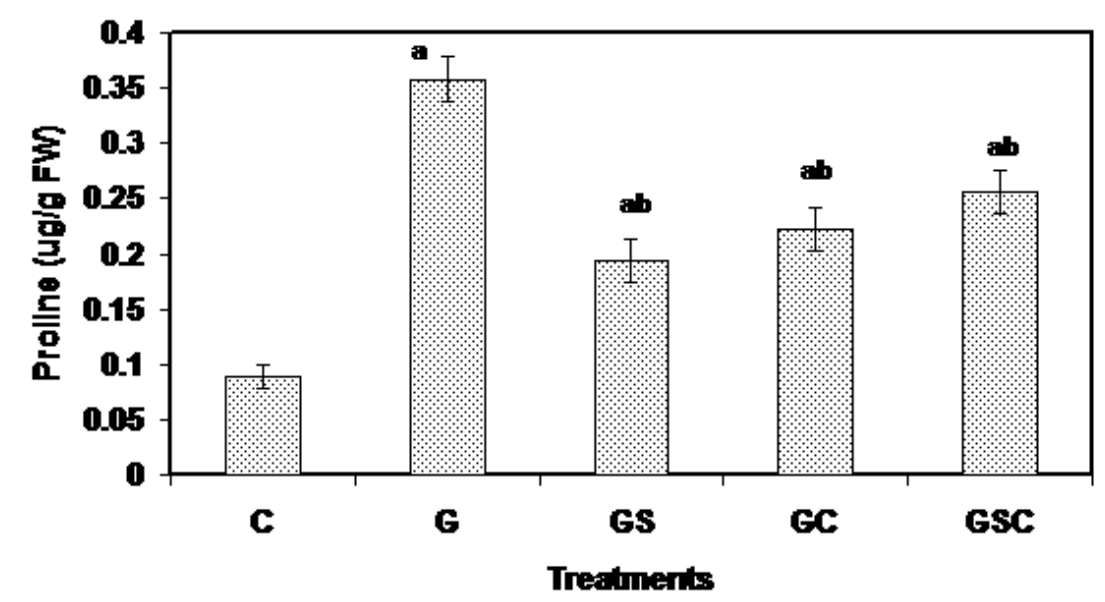

Fig.5. Effect of glyphosate, SA and CK applied alone and in combination on the proline contents of maize leaves.

Means within a column followed by a, b are significantly different from the C (control) and $\mathrm{G}$ (glyphosate) treated samples, respectively.

Effect of glyphosate, SA and CK applied alone and in combination on protein electrophoretic pattern of maize leaves.

The results showed that the protein profiles were represented by 5 major and common distinct bands with molecular weight of 40,50, 60, 80 and $220 \mathrm{kDa}$ (Fig.6). SDS-PAGE analysis of maize leaves revealed an almost identical protein pattern and band intensity variation for the different treatments with an exception of the $45 \mathrm{kDa}$ molecular mass protein band (Fig. 6), which was strongly stimulated in the GC and GSC line, but was not dependent upon glyphosate treatment. Accumulation of proteins of molecular weights 45 which induced by CK had a possible role in adaptation to glyphosate stress. Moldes et al.

Egypt. J. Agron. 35, No. 2 (2013) 
(2008) recorded that protein of $45 \mathrm{kDa}$ and its mRNA accumulated in the soybean plants which are tolerant to glyphosate stress. Concerning protein band of molecular weight $26 \mathrm{kDa}$, results showed that intensity of this protein increased in response to stress with or without SA and CK. Induction of $26 \mathrm{kDa}$ protein in maize plants has been peculated to represent osmotin that is involved in the rapid accumulation of proline and glucine betain during stress (Dell Aquila \& Spada, 1992). In maize plants, Zorb et al. (2004) detected three groups of differentially regulated proteins in roots and shoots under salt stress: (A) Proteins which are involved in protein biosynthesis and protein modifications by Kinase, (B) Enzymes of the carbon metabolism and (C) Enzymes of the nitrogen metabolism. In addition, several protein kinase and phosphatase are involved in response to salt stress (Serrano \& Gaxiola, 1994).

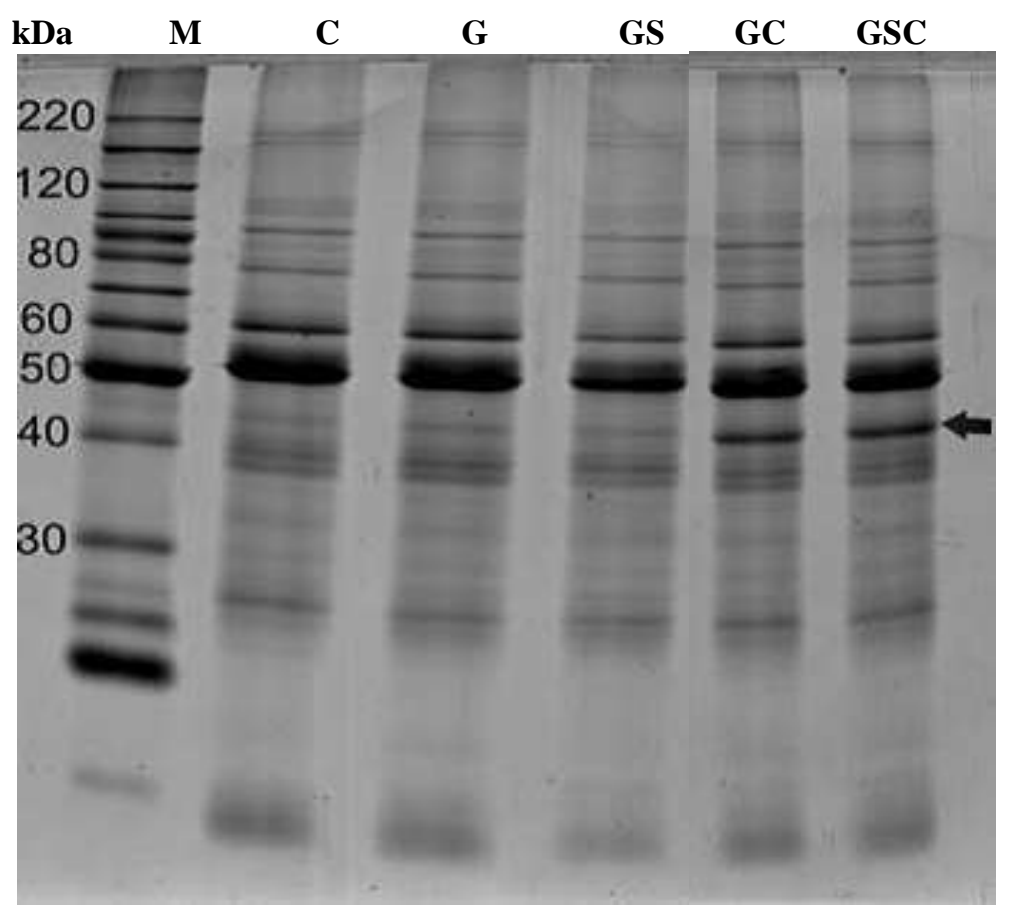

Fig.6. Effect of glyphosate, SA and CK applied alone and in combination on electrophoretic profiles of protein extracted from maize leaves.

Effect of glyphosate, SA and CK applied alone and in combination on the antioxidant enzyme activities of maize leaves

There are different enzymatic scavenging activities per a particular ROS can be found in the cell compartments. In this work, the activities of CAT, SOD and APX were slightly increased; meanwhile the activity of POD is highly induced in response to glyphosate (Fig.7). Moreover, SA treatment with glyphosate decrease the activities of the measured enzymes, meanwhile CK decrease the activities of CAT, SOD and POD but increase the activity of APX. Enzymatic 
ROS-scavenging pathways are important antioxidant defense mechanisms in plants. Among the set of antioxidant enzymes, SOD acts as a first line of defense response which converting the superoxide radical into $\mathrm{H}_{2} \mathrm{O}_{2}$ (Wang et al., 2004). Then $\mathrm{H}_{2} \mathrm{O}_{2}$ has to be further detoxified by CAT and/or POD or APX to water and oxygen (Shah et al., 2001). Detoxification of $\mathrm{H}_{2} \mathrm{O}_{2}$ prevents the oxidation of biological molecules and destruction of the cells (Liochev \& Fridovich, 1994). APX appears to play an essential role in the scavenging process when they coordinate with SOD (Wang et al., 2004). It is the initial enzyme that detoxifies cellular $\mathrm{H}_{2} \mathrm{O}_{2}$ through the activity of the ascorbate-glutathione scavenging cycle and serves as catalyzer in the reaction of ascorbate with $\mathrm{H}_{2} \mathrm{O}_{2}$ (Asada, 1999). CAT is one of the major antioxidant enzymes that eliminate hydrogen peroxide by converting it into oxygen and water. However, in most cases, the CAT activities were suppressed under various herbicides exposure except for seedlings stage (Gratã ot al., 2005).
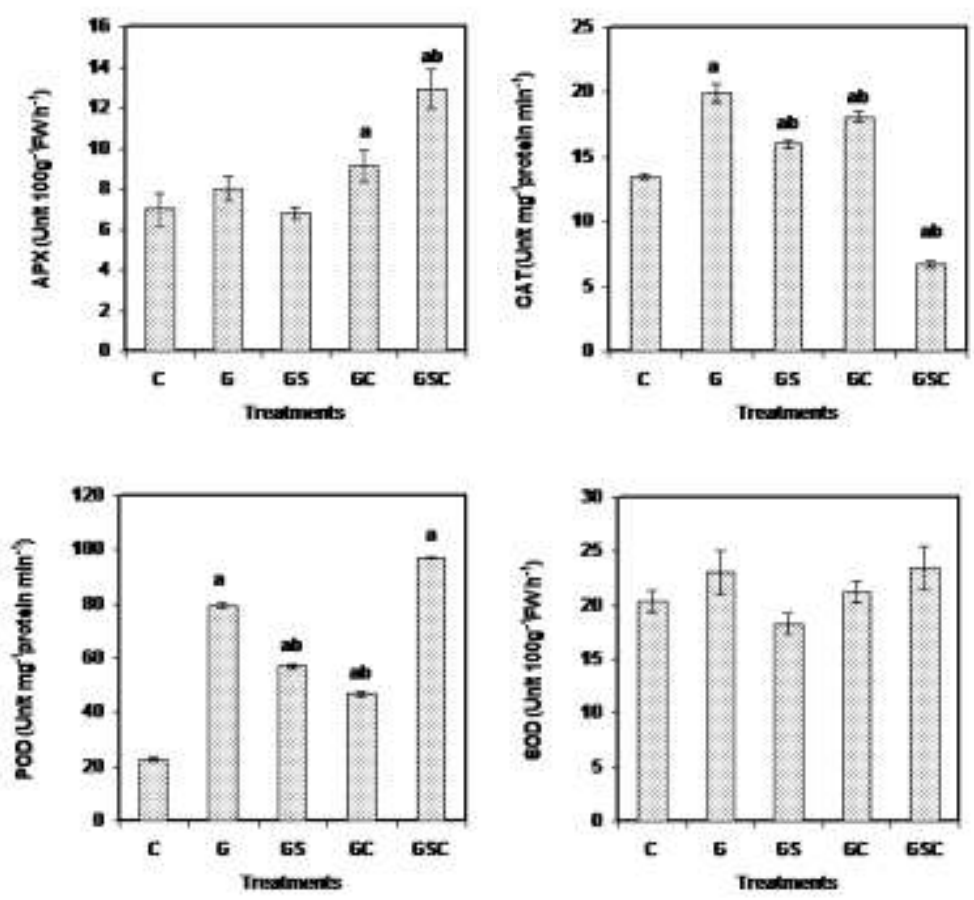

Fig.7. Effect of glyphosate, SA and CK applied alone and in combination on the antioxidant enzyme activities of maize leaves.

$\mathrm{APX}=$ Ascorbate peroxidase, $\mathrm{CAT}=$ Catalase, $\mathrm{POD}=$ Peroxidase, $\mathrm{SOD}=$ Superoxide dismutase .

Means within a column followed by $a, b$ are significantly different from the $C$ (control) and $G$ (glyphosate) treated samples, respectively.

According to Cui et al. (2010), it was possible that SA and CK would decrease ROS production and oxidative damage to plasma membrane, which consequently improved cell membrane integrity and prevented herbicides from 
entering the cells. The oxidative response in plants can be exacerbated by stressful conditions (Grata o et al., 2005). SA a signal molecule modifies the antioxidative system by inhibiting catalase and stimulating peroxidase enzymes (Rao et al., 1997). Obviously, the observed high activity of POD and low level of protein in SA treated maize plants discussed as a protective mechanism against glyphosate toxicity. Krantev et al. (2008) reported the exogenous application of SA enhanced the activities of antioxidant enzymes APX and SOD with a concomitant decline in the activity of CAT in maize plants. Inhibition of catalase by SA could serve as second messengers to induce the expression of plant defense related genes (Conarth et al., 1995).

\section{References}

Ananieva, E.A., Christov, L.P. and Popova, K.N. (2004) Exogenous treatment with salicylic acid leads to increased antioxidant capacity in leaves of barley plants exposed to paraquat $J$. Plant Physiol. 161, 319-328.

Apel, K. and Hirt, H. (2004) Reactive oxygen species: metabolism, oxidative stress, and signal transduction. Annu. Rev. Plant Biol. 55, 373-399.

Arfan, M., Athar, H.R. and Ashraf, M. (2007) Does exogenous application of salicylic acid through the rooting medium modulate growth and photosynthetic capacity in two differently adapted spring wheat cultivars under salt stress? J. Plant Physiol. 164, 685-694.

Argueso, C.T., Ferreira, F.J., Epple, P., To, J.P.C. and Hutchison, C.E. (2012) Twocomponent elements mediate interactions between cytokinin and salicylic acid in plant immunity. Plos Genet. 8 (1), 1-13.

Asada, K. (1999) The water-water cycle in chloroplasts: scavenging of active oxygens and dissipation of excess photons. Annu. Rev. Plant Physiol. Plant Mol. Biol. 50, $601-639$.

Ashraf, M. and Foolad, M.R. (2007) Roles of glycine betaine and praline in improving plant abiotic stress resistance. Environ. Exp.Bot. 59, 206-216.

Bates, L., Waldren, R. and Teare, I. (1973) Rapid determination of free proline for water-stress studies. Plant Soil, 39, 205-207.

Beauchamp, C. and Fridovich, I. (1971) Superoxide dismutase: improved assays and an assay applicable to acrylamide gels Anal. Biochem. 44, 276-287.

Bradford, M. (1976) A rapid and sensitive method for the quantification of microgram quantities of protein using the principle of protein-dye binding. Anal. Biochem. 72, $248-254$.

Burkhanova, E.A., Fedina, A. B. and Kulaeva, O. N. (1999) Effect of salicylic acid and $\left(2^{\prime}-5^{\prime}\right)$-oligoadenylates on protein synthesis in tobacco leaves under heat shock conditions: A comparative study. Russ. J. Plant Physiol. 46, 16-22.

Çag, S., Cevahir-öz, G., Sarsag, M. and Gören-Saglam, N. (2009) Effect of salicylic acid on pigment, protein content and peroxides activity in excised sunflower cotyledons. Pak. J. Bot. 41 (5), 2297-2303. 
Cakmak, I., Yazici, A., Tutus, Y. and Ozturk, L. (2009) Glyphosate reduced seed and leaf concentrations of calcium, manganese ,magnesium and iron in non-glyphosate resistant soybean. Eur. J. Agron. 31(3), 114-119.

Cho, U.H. and Seo, N.H. (2005) Oxidative stress in Arabidopsis thaliana exposed to cadmium is due to hydrogen peroxidases and ascorbate metabolism in plants. Phytochem. Rev. 3, 195-205.

Conarth, U., Chen, Z., Ricigliano, J. and Klessig, D.F. (1995) Two inducers of plant defense responses, 2, 6-dichloroisonicotinic acid and salicylic acid, inhibit catalase activity in tobacco. Proc. Natl. Acad. Sci. USA. 92, 7143-7147.

Conrad, R., Buchel, C., Wilhelm, C., Arsalane, W., Berkaloff, C. and Duval, J.C. (1993) Changes in yield in-vivo fluorescence of chlorophyll as a tool for selective herbicide monitoring. J. Appl. Phycol. 5, 505-516.

Cui, J., Zhang, R., Wu, G.L., Zhu, H.M. and Yang, H. (2010) Salicylic acid reduces napropamide toxicity by preventing its accumulation in rapeseed (Brassica napus L.) Arch. Environ. Contam. Toxicol. 59, 100-108.

Dayan, F.E., Duke, S. O. and Grossmann, K. (2010) Herbicides as probes in plant biology. Weed Sci. 58, 340-350.

Dell Aquila, A. and Spada, P. (1992) Regulation of protein synthesis in germinating wheat embryos under polyethylene glycol and salt stress. Seed Sci. Res. 2, 75-80.

El-Khallal, S.M., Hathout, T.A., Ahsour, A.A. and Kerrit, A.A. (2009) Brassinolide and salicylic acid induced antioxidant enzymes, hormonal balance and protein profile of maize plants grown under salt stress. Res. J. Agric. Biol. Sci. 5 (4), 391-402.

El-Taybe, M.A. and Zaki, H. (2009) Cytophysiological response of Vicia faba to glyphosate-based herbicide. American-Eurasian J. Agronomy, 2, 168-175.

Eraslan, A., Inal, A. and Gunes, M. (2007) Impact of exogenous salicylic acid on growth, antioxidant activity and physiology of carrot plants subjected to combined salinity and boron toxicity. Sci. Hort. 113, 120-128.

Franz, J.F., Mao, M.K. and Sikorski, J. A. (2000) Glyphosate - A Unique, global herbicide. American Chemical Society Monograph Series. American Chemical Society, Washington, DC, 688 pp.

Ge, X., d'Avignon, D.A., Ackerman, J. J.H. and Sammons, R. D. (2010) Rapid vacuolar sequestration: The horseweed glyphosate resistance mechanism. Pest Management Science, 66 (4), 345-8.

Gilreath, J. P., Chase, C.A. and Locascio, S. J. (2001) Crop injury from sublethal rates of herbicide. I. Tomato. Hort. Science, 36, 669-673.

Grata o, P.L., Polle, A., Lea, P.J. and Azevedo, R.A. (2005) Making the life of heavy metal-stressed plants a little easier. Funct. Plant Biol. 32, 481-494. 
Hassanein, R.A., Bassuony, F.M., Baraka, D.M. and Khalil, R.R. (2009) Physiological effects of nicotinamide and ascorbic acid on (Zea mays) plant grown under salinity stress. I- Changes in growth, some relevant metabolic activities and oxidative defense systems. Res. J. Agricult Biol. Sci. 5, 72-81.

Hawley, S.A., Fullerton, M.D., Ross, F.A., Schertzer, J.D., Chevtzoff, C., Walker, K.J., Peggie, M. W. and Zibrova, D. (2012) The ancient drug salicylate directly activates AMP-activated protein kinase. Science, 336 (6083), 918-940.

Hayat, Q., Hayat, S., Irfan, M. and Ahmad, A. (2010) Effect of exogenous salicylic acid under changing environment: A review. Environ. Exp. Bot. 68, 14-25.

Iqbal, M., Ashraf, M. and Jamil, A. (2006a) Seed enhancement with cytokinins: changes in growth and grain yield in salt stressed wheat plants. Plant Growth Regul. 50, 29-39.

Iqbal, M., Ashraf, M., Jamil, A. and Ur-Rehman, S. (2006b) Does seed priming induce changes in the levels of some endogenous plant hormones in hexaploid wheat plants under salt stress? J. Integ. Plant Biol. 48, 81-189.

Jiang, L. and Yang, H. (2009) Prometryne-induced oxidative stress and impact on antioxidant enzymes in wheat Ecotoxicol. Environ. Safety, 4, 25-32.

Khodary, S.F.A. (2004) Effect of salicylic acid on the growth, photosynthesis and carbohydrate metabolism in salt stressed maize plants. Int. J. Agric. Biol. 6, 5-8.

Kiadó, A. (2005) Reduction of paraquat toxicity in maize leaves by benzyladenine. Acta Biologica Hungarica, Biology, 56 (2), 97-107.

Kokkinakis, D.M. and Brooks, J.L. (1979) Tomato peroxidase: purification, characterization and catalytic properties. Plant Physiology, 63 (2), 93-99.

Krantev, A. Yordanova, R., Janda, T., Szalai, G. and Popova, L. (2008) Treatment with salicylic acid decreases the effect of cadmium on photosynthesis in maize plants J. Plant Physiol. 165, 920-931.

Laemmli, U.K. (1970) Cleavage of structural proteins during the assembly of the bacteriophage T4. Nature, 227, 680-685.

Letham, D.S. (1978) "Cytokinins: Phytohormones and Related Compounds". Elsevier, Amsterdam, 1, pp. 205-243.

Levy, M., Bachmair, A. and Adam, Z. (2004) A single recessive mutation in the proteolytic machinery of Arabidopsis chloroplasts impairs photoprotection and photosynthesis upon cold stress. Planta, 218, 396-405.

Liochev, S.I. and Fridovich, I. (1994) Paraquat diaphorases in Escherichia coli Free Radic. Biol. Med. 16, 555-559.

Liu, Z.J., Zhang, X.L., Bai, J.G., Suo, B.X., Xu, P.L. and Wang, L. (2009) Exogenous paraquat changes antioxidant enzyme actives and lipid peroxidation in droughtstressed cucumber leaves. Sci. Hortic. 121, 138-143. 
Liua, X., Huang, B. and Banowetz, G. (2002) Cytokinin effects on creeping bent grass responses to heat stress. Crop Sci. 42, 457-465.

Mafakheri, A., Siosemardeh, A., Bahramnejad, B., Struik, P.C. and Sohrabi, Y. (2010) Effect of drought stress on yield, proline and chlorophyll contents in three chickpea cultivars. Aust. J. Crop Sci. 4 (8), 580-585.

Maruyama, K., Sakuma, Y., Kasuga, M., Ito, Y., Seki, M., Goda, H., Shimada, Y., Yoshida, S., Shinozaki, K. and Yamaguchi-Shinozaki, K. (2004) Identification of cold-inducible downstream genes of the Arabidopsis. Plant Journal, 38, 982-993.

Mateos-Naranjo, E., Redondo-Gómez, S., Cox, L., Cornejo, J. and Figueroa, M.E. (2009) Effectiveness of glyphosate and imazamox on the control of the invasive cordgrass Spartina densiflora. Ecotox. Environ. Safe, 72, 1694-1700.

Merkouropoulos, G., Barnett, D.C. and Shirsat, A. H. (1999) The arabidopsis extensin gene is developmentally regulated, is induced by wounding, methyl jasmonate, abscisic and salicylic acid, and codes for a protein with unusual motifs. Planta, 208, 212-219.

Metzner, H., Rau, H. and Senger, H. (1965) Untersuchuger Zue Synchronisierbarkeit Einzelnar-pigment-mangel mutanten Von . Chlorella. Planta, 65, 186-194.

Mittler, R., Vanderauwera, S., Gollery, M. and Van Breusegem, F. (2004) The reactive oxygen gene network in plants. Trends Plant Sci. 9 (10), 490-498.

Moldes, C.A., Medici, L.O., Abraha o , O.S., Tsai, S.M. and Azevedo, R.A. (2008) Biochemical responses of glyphosate resistant and susceptible soybean plants exposed to glyphosate. Acta. Physiol .Plant, 30, 469-479.

Nakano, Y. and Asada, K. (1987) Purification of ascorbate peroxidase in spinach chloroplasts: its inactivation in ascorbate depleted medium and reactivation by monodehydroascorbate radical. Plant Cell Physiol. 28, 131-140.

Nandula, V.K., Reddy, K.N., Rimando, A.M., Duke, S.O. and Poston, D.H. (2007) Glyphosate-resistant and susceptible soybean (Glycine max) and canola (Brassica napus) dose response and metabolism relationships with glyphosate. J. Agric .Food Chem. 55, 3540-3545.

Noreen, S., Ashraf, M., Hussain, M. and Jamil, A. (2009) Exogenous application of salicylic acid enhances antioxidative capacity in salt stressed sunflower (Helianthus annuus L.) plants. Pak. J. Bot. 41(1), 473-479.

Ogweno, J.O., Song, X.S., Hu, W.H., Shi, K., Zhou, Y.H. and Yu, J.Q. (2009) Detached leaves of tomato differ in their photosynthetic physiological response to moderate high and low temperature stress. Sci. Hortic. 123, 17-22.

Peixoto, F., Alves-Fernandes, D., Santos, D. and Fontaínhas-Fernandes, A. (2006) Toxicological effects of oxyfluorfen on oxidative stress enzymes in tilapia Oreochromis niloticus Pest. Biochem. Physiol. 85, 91-96.

Peleg, Z. and Blumwald, E. (2011) Hormone balance and abiotic stress tolerance in crop plants. Plant Biology, 14 (3), 290-295.

Egypt. J. Agron. 35, No. 2 (2013) 
Pospisilova, J. (2003) Interaction of cytokinins and abscisic acid during regulation of stomatal opening in bean leaves. Photosynthetica, 41, 49-56.

Radwan, M.D. (2012) Salicylic acid induced alleviation of oxidative stress caused by clethodim in maize (Zea mays L.) leaves. Pesticide Biochemistry and Physiology, 102 (2), 182-188.

Rao, M.V., Paliyath, G., Ormrod, D.P., Murr, D.P. and Watkins, C.B. (1997) Influence of salicylic acid on $\mathrm{H}_{2} \mathrm{O}_{2}$ production, oxidative stress, and $\mathrm{H}_{2} \mathrm{O}_{2}$ metabolizing enzymes (salicylic acid-mediated oxidative damage requires $\mathrm{H}_{2} \mathrm{O}_{2}$ ). Plant Physiol. 115, 137-149.

Salbego, J., Pretto, A., Gioda, C.R., Menezes, C.C., Lazzari, R., Radünz, N.J., Baldisserotto, B. and Loro, V. L. (2010) Herbicide formulation with glyphosate affects growth, acetylcholinesterase activity, and metabolic and hematological parameters in piava (Leporinus obtusidens). Archives of Environmental Contamination and Toxicology, 58 (3), 740-5.

Santos, C.V. (2004) Regulation of chlorophyll biosynthesis and degradation by salt stress in sunflower leaves. Sci. Hortic. Amsterdam, 103, 93-99.

Schmidt, R. and Zhang, X. (1997) Influence of seaweed extracts on growth and stress tolerance of grasses, in: Proceedings of American Forage and Grassland Council, M. Williams (Ed.), Georgetown, TX, pp. 158-162.

Sergiev, I.G., Alexieva, V.S., Ivanov, S.V., Moskova, I.I. and Karanov, E.N. (2006) The phenylurea cytokinin 4PU-30 protects maize plants against glyphosate action. Pestic. Biochem. Physiol. 85,139-146.

Serrano, R. and Gaxiola, R. (1994) Microbial models and salt tolerance in plants. Crit. Rev. Plant Sci. 13, 121-138.

Shah, K., Kumar, R.G., Verma, S. and Dubey R.S. (2001) Effect of cadmium on lipid peroxidation, superoxide anion generation and activities of antioxidant enzymes in growing rice seedlings. Plant Sci. 161, 1135-1144.

Singh, N.B., Yadav, K. and Amist, N. (2012) Mitigating effects of salicylic acid against herbicidal stress. Journal of Stress Physiology \& Biochemistry, 8 (4), 27-35.

Skinner, C.G., Talbert, F. D. and Saive, W. (2009) " The Manual of Biocontrol Agents". Alton, UK: BCPC.

Song, N.H., Chen, L. and Yang, H. (2008) Effect of dissolved organic matter on mobility and activation of chlorotuluron in soil and wheat. Geoderma, 146, 344-352.

Stephen, O.D. and Stephen, B.P. (2008) Glyphosate: a once-in-a-century herbicide. Pest Management Science, 64, 319-325.

Tan, S., Evans, R. and Singh, B. (2006) Herbicidal inhibitors of amino acid biosynthesis and herbicide-tolerant crops. Amino Acids, 30, 195-204.

Tu, C.M. (1994) Effects of herbicides and fumigants on microbial activities in soil Bulletin of Environmental Contamination and Toxicology, 53, 12-17. 
Velikova, V., Yordanov, I. and Edreva, A. (2000) Oxidative stress and some antioxidant systems in acid rain-treated bean plants. Protective role of exogenous polyamines. Plant Sci. 151, 59-66.

Vila-Aiub, M.M., Balbi, M. C., Gundel, P. E., Ghersa, C.M. and Powles, S.B. (2007) Evolution of Glyphosate-Resistant Johnsongrass (Sorghum halepense) in Glyphosate-Resistant Soybean. Weed Science, 55 (6), 566-71.

Vila-Aiub, M.M., Vidal, R.A., Balbi, M.C., Gundel,P. E., Trucco, F. and Ghersa, C. M. (2008) Glyphosate-resistant weeds of South American cropping systems: an overview. Pest Management Science, 64 (4), 366-71.

Vogel, J.T., Zarka, D. G., Van Buskirk, H. A., Fowler, S.G. and Thomashow, M.F. (2005) Roles of the CBF2 and ZAT12 transcription factors in configuring the low temperature transcriptome of Arabidopsis. Plant Journal, 41, 195-211.

Wang, Y.S., Wang, J., Yang, Z.M., Lu, B., Wang, Q.Y., Li, S.Q., Lu, Y.P., Wang, S.H. and Sun, X. (2004) Salicylic acid modulates aluminum induced oxidative stress in roots of Cassia tora L. Bot. Stud. 46, 819-828.

Wei, X., Wang, L.M., Long, R.J. and Wang, G.X. (2006) Effects of exogenous nitric oxide, salicylic acid and hydrogen peroxide on free amino acid and soluble protein contents in tobacco leaves. J.Exp. Bot. 32, 257-260.

Xia, J., Zhao, H., Liu, W., Li, L. and He, H. (2008) Role of cytokinin and salicylic acid in plant growth at low temperatures. Plant Growth Regulation, 8, 9338-9346.

Xu, S., Li, J., Zhang, X., Wei, H. and Cui, L. (2006) Effects of heat acclimation pretreatment on changes of membrane lipid peroxidation, antioxidant metabolites, and ultrastructure of chloroplasts in two cool-season turfgrass species under heat stress. Environ. Exp. Bot. 56, 274-285.

Yancey, P., Clark, M., Hand, S., Bowlus, R. and Somero, G. (1982) Living with water stress: Evolution of osmolyte systems. Science, 217, 1214-1222.

Yin, X.L., Jiang, L., Song, N.H. and Yang, H. (2008) Toxic reactivity of wheat (Triticum aestivum) plants to herbicide isoproturon. J. Agric. Food Chem. 56, 48254831.

Zaidi, A., Khan, M.S. and Rizvi, P.Q. (2005) Effect of herbicides on growth, nodulation and nitrogen content of green gram. Agron. Sustain. 2, 56-64.

Zhang, H.X. and Schmidt, R. (2000) Hormone-containing products impact on antioxidant status of tall fescue and creeping bent grass subjected of drought. Crop Sci. 40, 1344-1349.

Zhang, H.X., Hodson, J.N., Williams, J.P. and Blumwald, E. (2001) Engineering salttolerant Brassica plants: Characterization of yield and seed oil quality in transgenic plants with increased vacuolar sodium accumulation. Natl. Acad. Sci. 98, 12832 12836 . 
Zorb, C., Scmitt, S., Neeb, A., Karl, S., Linder, M. and Schubert, S. (2004) The biochemicsl reaction of maize (Zea mays L.) to salt stress is characterized by a mitigation of symptoms and by specific adaptation. Plant Sci. 167, 91-100.

(Received 30/7/2013;
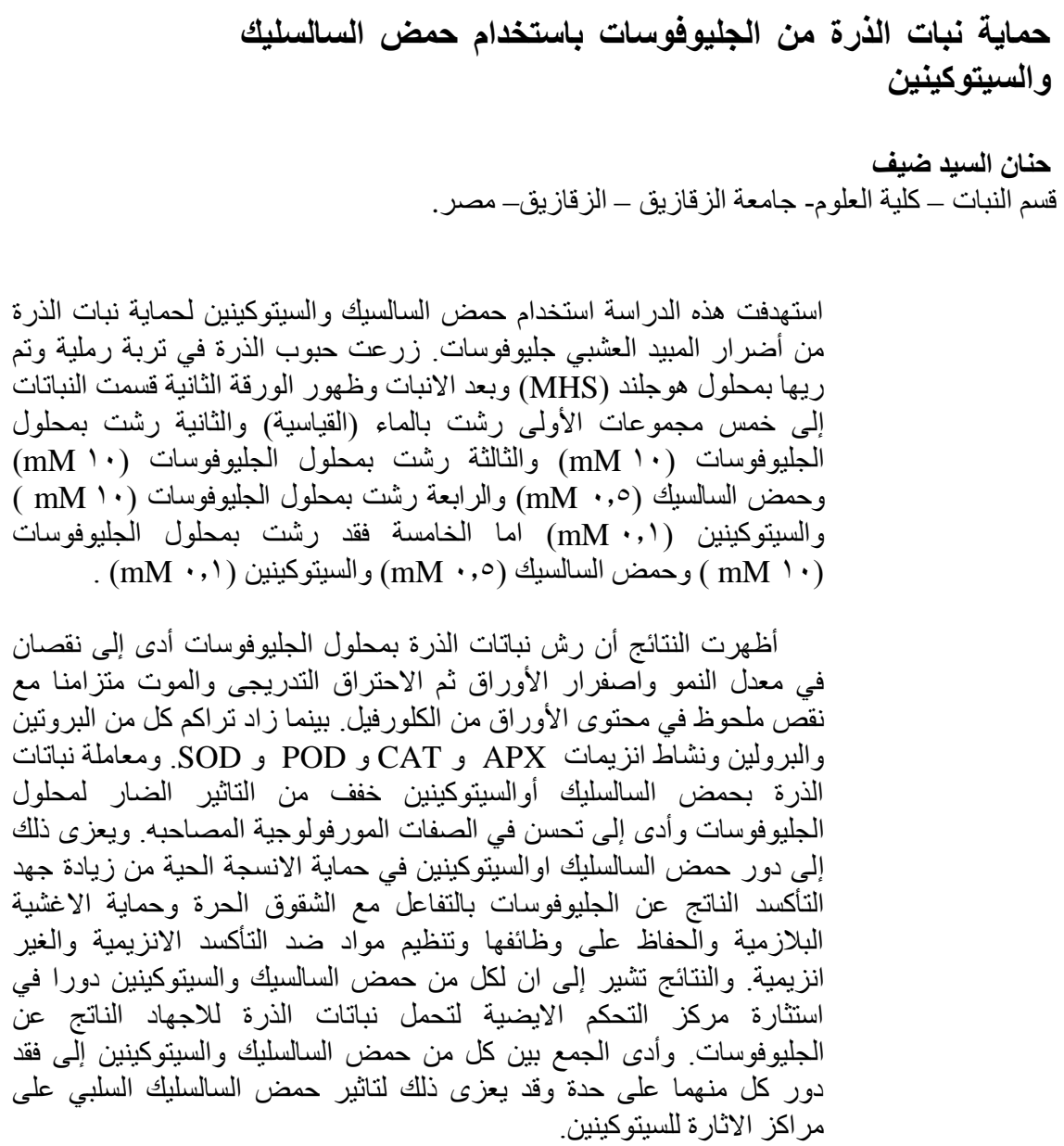